\title{
Analysis of the effect of service quality, food quality, atmospherics, authenticity (food), and authenticity (atmospheric), to positive emotion, value, and behavioral intention to myoung ga korean restaurant customer in Surabaya
}

\author{
Dennys Christian, Amelia ${ }^{\mathrm{a}}$, Ronald ${ }^{\mathrm{b} *}$ \\ a dennyschristian93@gmail.com \\ ${ }^{a}$ Master of Management Student at Pelita Harapan University, Surabaya 60234, Indonesia \\ ${ }^{b, c}$ The Lecturer of Master of Management at Pelita Harapan University, Surabaya 60234, Indonesia
}

\begin{abstract}
The appearance of the Korean Wave was marked for the first time by the presence of his dramas that managed to captivate Indonesian audiences. The rise of Korean dramas that have entered Indonesia seems to open new avenues for other Korean cultures to enter the country, one of which is culinary delights which are marked by the emergence of Korean restaurants in big cities of Indonesia. Myoung Ga, is the first Korean restaurant standing in the city of Surabaya and appears with the identity of its traditional dishes. Until more than 20 years have passed, this restaurant has survived and is actually able to compete with new and more modern Korean restaurants.

This study aims to determine how the influence of Service Quality, Food Quality, Atmospherics, Authenticity (Food), and Authenticity (Atmospherics) on Positive Emotion, Value and Behavioral Intention. The expected benefit from this research is to add to the knowledge in the field of management, especially how much positive emotion is influenced by increasing behavioral intentions, which in turn will increase sustainable transactions from customers of Myoung Ga Korean Restaurant in Surabaya.

This research is a causal research. The research method used is a quantitative method with data processing using SPSS. Data collection was carried out by distributing questionnaires to 165 respondents with the characteristics of male and female respondents aged 18-60 years, residing in Surabaya and having bought and consumed (dine in) food and beverages Restaurant Myoung Ga in Surabaya at least 2 times in the last 2 years.

The results showed that positive emotion has a significant effect on repurchase intention with a regression coefficient of 0.520 and perceived value also has a significant effect on behavioral intentions with a regression coefficient of 0.391 . Meanwhile, perceived value has a significant effect on positive emotion with a regression coefficient of 0.363 , service quality has a significant effect on perceived value with a regression coefficient of 0.251 , atmosphere has a significant effect on perceived value with a regression coefficient of 0.244 , food quality also has a significant effect on perceived value with a regression coefficient. 0.237, authenticity (atmosphere) has a significant effect on perceived value with a regression coefficient of 0.165 , food quality has a significant effect on positive emotion with a regression coefficient of 0.157 , authenticity (food) has a significant effect on positive emotion with a regression coefficient of 0.142 , authenticity (food) significant effect on Perceived value with a regression coefficient of 0.142 , authenticity (atmosphere) has a significant effect on positive emotion with a regression coefficient of 0.123 , service quality has significant influence on positive emotion with a regression coefficient of 0.131 , and atmosphere has a significant effect on positive emotion with a regression coefficient of 0.114 .
\end{abstract}


Published by IJRP.ORG. Selection and/or peer-review under responsibility of International Journal of Research Publications (IJRP.ORG)

\section{Background}

Popular culture at this time is not only dominated by westerns, but one of the cultures that is currently influencing various countries around the world is Korean pop culture or better known as Hallyu. Including Indonesia, where the country is also strongly affected by Hallyu. The spread of Korean pop culture is also helped by various mass media and the role of the government in actively introducing the culture. The culture is continuously being disseminated via television (www.kompasiana.com, downloaded on 7 July 2020).

The Hallyu phenomenon always presents Korean cultural commodities. In commodities of music, drama, lifestyle, fashion, language and cuisine are always well introduced in entertainment program contents (Lee, 2011: 2). In the Indonesian entertainment market itself, Hallyu captivates the wider community with entertainment shows and a type of Korean music called Korean Pop (Korean Pop Music) or better known as a shorter term, namely K-pop. The creative economy industry continues to develop into the realms of crafts, lifestyle, culture and food (www.beritasatu.com, downloaded on July 7, 2020).

One of the strongest Korean cultures that enter Indonesia is food and drink. The number of Korean drama scenes that show their food, ranging from roadside snacks, home food, to various types of restaurants serving their special food, of course, make the drama audience interested in their food. South Korea itself is known for its rich culinary delights. Their unique and interesting street food to their home food culture which has many types of side dishes has succeeded in making many local and foreign culinary entrepreneurs see a great opportunity to start a Korean food business in Indonesia (www.kinibisa.com, downloaded on June 9 July 2020).

This is finally evident from the ease with which Korean restaurants and supermarkets have been found since the entry of the Korean Wave to Indonesia. If in the past Korean food restaurants were difficult to find, now many Korean restaurants are located in various locations, especially Jakarta, which are favorites of Korean culture fans. For example, Mujigae, Kyochon, Mr. Park, Chung Gi Wa, Ojju, etc. Even supermarkets such as Lotte Mart and K-Mart are also a testament to the huge impact of the Korean Wave in spreading South Korean food culture in the community, seen from the great enthusiasm of the community for things like this (www.kinibisa.com, downloaded on July 9, 2020).

This is evident from the increasing number of Korean restaurants and supermarkets that have started businesses since the entry of the Korean Wave to Indonesia. If in the past Korean food restaurants were difficult to find, now many Korean restaurants are located in various locations, especially Jakarta, which are favorites of Korean culture fans. For example, Mujigae, Kyochon, Mr. Park, Chung Gi Wa, Ojju, etc. Even supermarkets such as Lotte Mart and K-Mart are also a testament to the huge impact of the Korean Wave in spreading South Korean food culture in the community, seen from the great enthusiasm of the community for things like this (www.kinibisa.com, downloaded on July 9, 2020) . 
Besides DKI Jakarta, which is the entrance gate as well as the epicenter of the Korean Wave in Indonesia, the city of Surabaya which is the second largest city in Indonesia also has various Korean restaurants with their respective advantages, including Seoul City, Ahjumma Kithchen, Ojju, Gojumong, Magal Korean BBQ, Myoung Ga, etc. But despite the many Korean restaurants in Surabaya, Myoung Ga is the only Korean restaurant that is the most senior and most authentic, so it attracts its customers to always come back (www.foodgrapher.com, downloaded on July 9, 2020).

\section{Litterature Review}

The Effect of Service Quality on Positive Emotions

The environment and services of a restaurant affect the value received by customers through emotional and cognitive responses. In general, employee service, food, and dining environment have been considered the three most important features of a restaurant (Susskind and Chan, 2000; Jang and Namkung, 2009). Service quality has been viewed as a customer cognitive evaluation of the services provided (Taylor and Baker, 1994), which is a critical predictor of customer satisfaction and post-consumption behavior. As such, service quality has been extensively researched in the field of service marketing. In particular, perceptions of service quality in restaurants are highly dependent on the relationship between customers and service providers and employee performance (Nikolich and Sparks, 1995).

H1: Service Quality has a significant effect on Positive Emotions.

\section{Thw Effect of Service Quality on Perceived Value}

Choi and Kim (2013, p. 241) state that the perceived quality of services and products affects how high the value perceived by customers is. Quality service shows that the service meets customer expectations. When the service has customer expectations, the customer feels that the service has high value. For this reason, the level of perceived service quality determines the level of perceived value perceived by customers. Tushi (2014, p. 14) explains that the creation of value in service marketing depends on a commitment to providing superior service (committed to continuously create superior customer value), meaning that when the service provided by the provider is carried out with high quality, it will be able to build value. in consumers. High service quality means being able to touch various aspects of the service so as to provide more benefits for consumers

H2: Service Quality has a significant effect on Perceived Value.

\section{The Effect of Food Quality on Positive Emotion}

Previous research has suggested that various food attributes are considered a real cue (Jang, Ha, \& Park, 2012). Customers use cues to determine food quality, which significantly influences satisfaction and behavior. Thus, the high quality of food causes more positive emotions and provides a better perception of value regarding the experience when dining at a restaurant.

H3: Food Quality has a significant effect on Positive Emotions.

The Effect of Food Quality on Perceived Value

In the restaurant industry, food is also considered as one of the most important factors that lead to satisfaction and loyalty (Clark and Wood, 1999; Namkung and Jang, 2007; Sulek and Hensley, 2004). Previous studies examined the importance of food quality in restaurant marketing assessing food quality using various food attributes, such as presentation, menu variation, healthy choices, taste, freshness, and temperature (Kivela et al., 2000; Raajpoot, 2002; Namkung and Jang, 2007) .

H4: Food Quality has a significant effect on Perceived Value.

The Effect of Atmospherics on Positive Emotions

Atmospherics according to Kotler (1973) is an attempt to design a purchasing environment in order to produce 
certain emotional effects on consumers in order to increase the probability of buying. Meanwhile, according to Kotler (1973) Atmospherics can be a marketing tool to produce positive behavior in a consumption situation where the product or service is consumed (Ha \& Jang, 2010).

H5: Atmospherics has a significant effect on Positive Emotions.

The Effect of Atmospherics on Perceived Value

The atmosphere is a planned atmosphere in accordance with the target market and which can attract consumers to buy (Kotler, 2005). Levy and Weitz (2007) consumer buying behavior is also influenced by the amosphere. Liberman (2002) states that the interior of a restaurant will determine whether a restaurant can survive or not.

H6: Atmospherics has a significant effect on Perceived Value.

\section{The Effect of Authenticity of Food on Positive Emotions}

The unique environment of an ethnic restaurant can add pleasure value for consumers which is reflected in the authenticity of the food and to taste or experience other cultures as well as a means of communication between food, foreign cultures and local customers (Jang and Ha, 2012: 204; Van den Berghe 1984, in Clemes, 2013 : 414; Wood and Munoz 2007, in Jang et al, 2011: 663).

H7: Authenticity of Food has a significant effect on Positive Emotions.

\section{The Effect of Authenticity of Food on Perceived Value}

Typical restaurants reflect their own culture to attract customers. According to Liu and Jang (2009b), authenticity (Authenticity) refers to whether the food and the environment reflect a reality of "authenticity" of a certain ethnic culture. Meanwhile, according to Wood and Munoz (2006), some experts conclude that even describing a typical restaurant as two cultures from the country of origin and the experience of eating at a typical restaurant is considered a culinary tour.

H8: Authenticity of Food has a significant effect on Perceived Value.

\section{The Effect of Authenticity of Atmospherics on Positive Emotions}

Ethnic restaurant is a restaurant that combines themes or concepts that lead to the ethnicity of an area with cuisine in order to add to the experience for its consumers (Walker, 2009: 218; Barrows et al, 2012: 73). Authenticity prioritizes food and the characteristics of a certain regional cultural tradition so that it can reflect the true taste of the cultural environment of a particular ethnicity (Ebster and Guist, 2004: 43, in Maria Anggia, 2014: 978; Verbeke and López, 2005 in Jang et al, 2012: 993).

H9: Authenticity of Atmospherics has a significant effect on Positive Emotions.

\section{The Effect of Authenticity of Atmospherics on Perceived Value}

The existence of an atmospheric aspect in a restaurant is one of the reasons for the desire for consumers to visit and make purchases. Hughes, 1995; Wang, 1999; Kim et.al, 2009; in Jahromy \& Tajik, 2011: 17 argues that "authenticity is considered one of the factors that influence the experience of tourists visiting a restaurant. Authenticity connotes traditional origin and culture, authentic, real and unique taste.

H10: Authenticity of Atmosphere has a significant effect on Perceived Value.

\section{The Effect of Perceived Value on Behavioral Intentions}

According to Zaithaml (1998), stated that perceived value plays an important role in consumer purchasing decisions, indicating that behavioral intention is a consequence of perceived value (Ha \& Jang, 2010). Ryu, Han, and Kim (2008) examined the relationship between restaurant image, perceived value, customer satisfaction, and behavioral intentions in casual restaurants and found that perceived value had a significant role in influencing behavioral intentions.

H11: Perceived Value has a significant effect on Behavioral Intentions. 
The Effect of Perceived Value on Positive Emotions

Research conducted by Rachmawati (2009) when value is combined with positive emotion, then any increase or decrease in value can affect impulse buying. Research conducted by Rohman (2009) also obtained the same results where the more positive influence of the consumer's mood, the higher the hedonic consumption value. Research conducted by Amiri et al. (2012) shows that hedonic competition tendency has a positive effect on positive emotion during impulse buying.

H12: Perceived Value has a significant effect on Positive Emotions.

The Effect of Positive Emotions on Behavioral Intentions

According to Jang and Namkung (2009) and Liu and Jang (2009a, b), using the development of the MehrabianRussell model also found that the emotions generated by dining factors significantly influence consumer behavior in the future, such as positive revisit intentions and worth of mouth. Empirical research shows a positive relationship between positive emotions and behavioral intention in different service environments.

H13: Positive Emotion has a significant effect on Behavioral Intentions.

\section{Research Model}

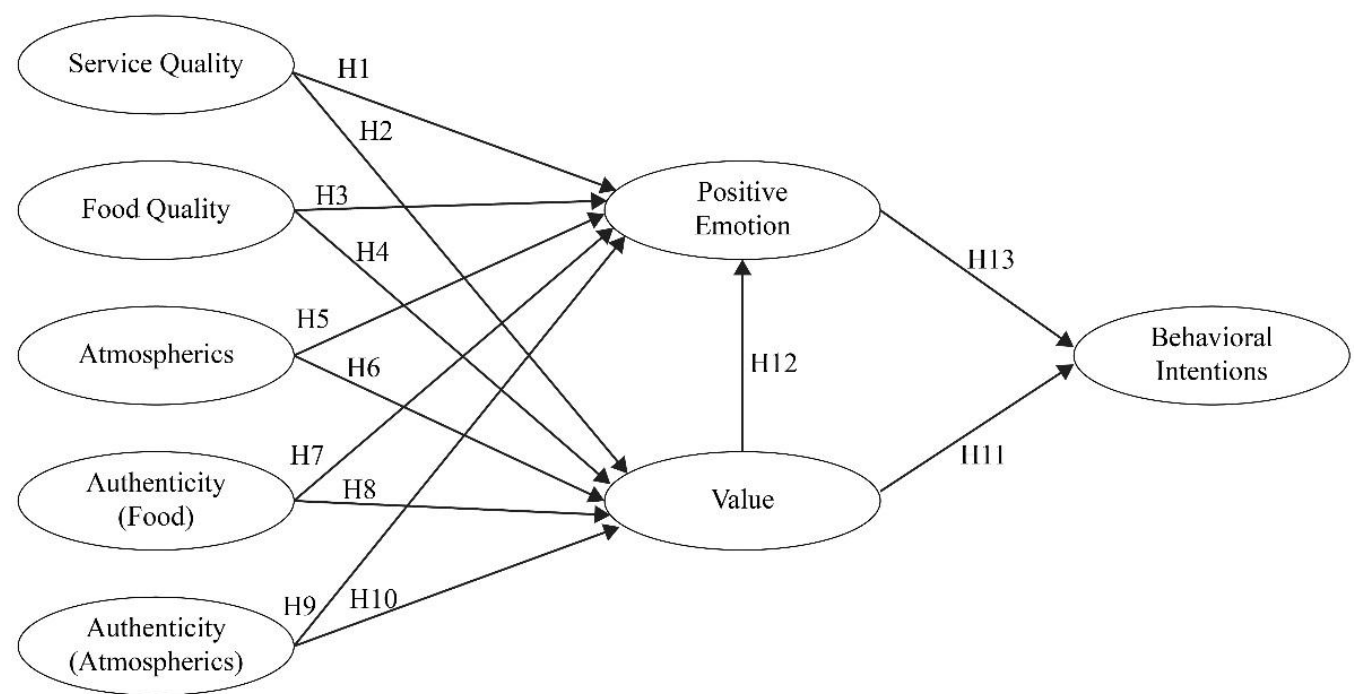

\section{Research Method}

This data collection was carried out using a questionnaire distributed to respondents in accordance with the characteristics of the sample previously described, namely, by using primary data. The questionnaire is filled in at the place where the respondent is when the questionnaire has been given and then it will be selected. Only data from the questionnaire that has been completely filled in and according to the filling instructions will be processed further. The city of Surabaya is an area that is used as a place for distributing questionnaires and is given to users who have made purchases at Korean restaurant Myoung Ga Surabaya for the last six months. The questionnaire was given repeatedly so that the respondents were selected according to what was expected. The questionnaire must be distributed to respondents who have decided to buy, so as not to provide social pressure and disturb consumers (Cobb \& Hoyer, 1986). In this study, the questionnaire will be given to respondents after 
the respondent makes a purchase at the Myoung Ga restaurant. The questionnaire was given to customers of the Myoung Ga restaurant, so that the respondents were selected according to what was expected. Furthermore, tabulating the results of the respondents' research, and testing the research model using SPSS version 22.0 software. The questionnaire that will be used in this study consists of two parts, namely the first part contains questions to obtain personal information of the respondent which has the use of determining the suitability of the characteristics of the respondents with the sample criteria. The second part of the questionnaire contains questions to obtain research data and analyze the influence relationship between Service Quality, Food Quality, Atmospherics, Authenticity (Food) and Authenticity (Atmospherics) on Positive Emotions, Perceived Value through Behavioral Intentions. The scale used in this study is the Likert scale, where answers are provided at intervals from strongly disagree (STS) to strongly agree (SS).

\section{Results and Discussion}

Multiple Regression $S Q, F Q, A T, A U F, A U A$ to $V A$

\begin{tabular}{|c|c|c|c|c|c|c|c|c|}
\hline \multirow{2}{*}{\multicolumn{2}{|c|}{ Model }} & \multicolumn{2}{|c|}{$\begin{array}{c}\text { Unstandardized } \\
\text { Coefficients }\end{array}$} & \multirow{2}{*}{$\begin{array}{c}\begin{array}{c}\text { Standardized } \\
\text { Coefficients }\end{array} \\
\text { Beta }\end{array}$} & \multirow[b]{2}{*}{$\mathrm{t}$} & \multirow[b]{2}{*}{ Sig. } & \multicolumn{2}{|c|}{$\begin{array}{c}\text { Collinearity } \\
\text { Statistics } \\
\end{array}$} \\
\hline & & B & Std. Error & & & & Tolerance & VIF \\
\hline \multirow[t]{6}{*}{1} & (Constant) & .218 & .136 & & 1.608 & .110 & & \\
\hline & SQ & .233 & .061 & .251 & 3.795 & .000 & .258 & 3.879 \\
\hline & FQ & .198 & .043 & .237 & 4.584 & .000 & .422 & 2.369 \\
\hline & AT & .235 & .048 & .244 & 4.843 & .000 & .444 & 2.254 \\
\hline & AUF & .141 & .062 & .142 & 2.269 & .025 & .288 & 3.476 \\
\hline & AUA & .153 & .061 & .165 & 2.492 & .014 & .257 & 3.894 \\
\hline
\end{tabular}

a. Dependent Variable: VA

Multiple Regression $S Q, F Q, A T, A U F, A U A, V A$ to $P E$

\begin{tabular}{|c|c|c|c|c|c|c|c|c|}
\hline \multirow{2}{*}{\multicolumn{2}{|c|}{ Model }} & \multicolumn{2}{|c|}{$\begin{array}{c}\text { Unstandardized } \\
\text { Coefficients }\end{array}$} & \multirow{2}{*}{$\begin{array}{c}\text { Standardized } \\
\text { Coefficients } \\
\text { Beta } \\
\end{array}$} & \multirow[b]{2}{*}{$\mathrm{t}$} & \multirow[b]{2}{*}{ Sig. } & \multicolumn{2}{|c|}{$\begin{array}{c}\text { Collinearity } \\
\text { Statistics }\end{array}$} \\
\hline & & B & Std. Error & & & & Tolerance & VIF \\
\hline \multirow[t]{7}{*}{1} & (Constant) & .002 & .125 & & .016 & .987 & & \\
\hline & SQ & .125 & .059 & .131 & 2.131 & .035 & .236 & 4.230 \\
\hline & FQ & .134 & .042 & .157 & 3.192 & .002 & .373 & 2.682 \\
\hline & AT & .113 & .048 & .114 & 2.373 & .019 & .387 & 2.586 \\
\hline & AUF & .145 & .058 & .142 & 2.502 & .013 & .279 & 3.588 \\
\hline & AUA & .117 & .057 & .123 & 2.043 & .043 & .247 & 4.046 \\
\hline & VA & .372 & .073 & .363 & 5.115 & .000 & .179 & 5.583 \\
\hline
\end{tabular}


Single Regression PE, VA to BI

\begin{tabular}{|c|c|c|c|c|c|c|c|c|}
\hline \multirow{2}{*}{\multicolumn{2}{|c|}{ Model }} & \multicolumn{2}{|c|}{$\begin{array}{c}\text { Unstandardized } \\
\text { Coefficients }\end{array}$} & \multirow{2}{*}{$\begin{array}{c}\begin{array}{c}\text { Standardized } \\
\text { Coefficients }\end{array} \\
\text { Beta } \\
\end{array}$} & \multirow[b]{2}{*}{$\mathrm{t}$} & \multirow[b]{2}{*}{ Sig. } & \multicolumn{2}{|c|}{$\begin{array}{c}\text { Collinearity } \\
\text { Statistics } \\
\end{array}$} \\
\hline & & B & Std. Error & & & & Tolerance & VIF \\
\hline \multirow[t]{3}{*}{1} & (Constant) & .032 & .157 & & .203 & .840 & & \\
\hline & $\mathrm{PE}$ & .565 & .087 & .520 & 6.475 & .000 & .205 & 4.881 \\
\hline & VA & .436 & .090 & .391 & 4.876 & .000 & .205 & 4.881 \\
\hline
\end{tabular}

a. Dependent Variable: BI

Multiple regression test shows the influence of an independent variable on the dependent variable. The condition for a hypothesis is considered significant when the significance level is less than $0.05(\alpha=5 \%)$. So that the results in this study are explained as follows:

\begin{tabular}{|l|l|}
\hline Hypotheses & Analysis \\
\hline H1: Service Quality has a significant effect on Positive Emotions. & Accepted \\
\hline H2: Service Quality has a significant effect on Perceived Value. & Accepted \\
\hline H3: Food Quality has a significant effect on Positive Emotions. & Accepted \\
\hline H4: Food Quality has a significant effect on Perceived Value. & Accepted \\
\hline H5: Atmospherics has a significant effect on Positive Emotions. & Accepted \\
\hline H6: Atmospherics has a significant effect on Perceived Value. & Accepted \\
\hline H7: Authenticity of Food has a significant effect on Positive Emotions. & Accepted \\
\hline H8: Authenticity of Food has a significant effect on Perceived Value. & Accepted \\
\hline H9: Authenticity of Atmospherics has a significant effect on Positive Emotions. & Accepted \\
\hline H10: Authenticity of Atmosphere has a significant effect on Perceived Value. & Accepted \\
\hline H11: Perceived Value has a significant effect on Behavioral Intentions. & Accepted \\
\hline H12: Perceived Value has a significant effect on Positive Emotions. & Accepted \\
\hline H13: Positive Emotion has a significant effect on Behavioral Intentions. & Accepted \\
\hline
\end{tabular}

From the thirteen hypotheses studied, it was found that all of these hypotheses were accepted. The first hypothesis is that Service Quality has a significant effect on Positive Emotions. This hypothesis is supported by the $t$ test where the significance is 0.035 (below 0.05) which indicates that this hypothesis is accepted. Susskind and Chan (2000); Jang and Namkung (2009) suggest that the environment and services of a restaurant affect the value received by customers through emotional and cognitive responses. In general, employee service, food, and dining environment have been considered the three most important features of a restaurant. From the research results, it was found that when the employee service of the Myoung Ga Korean Restaurant in Surabaya was good, the food served was good, and the environment was also good, it would increase positive emotions, feel overall satisfied with employee service, satisfied with food, and satisfied with the environment of Myoung Ga Korean Restaurant in Surabaya.

Then in the second hypothesis, Service Quality has a significant effect on Perceived Value. This hypothesis is 
supported by the t test where the significance is 0.000 (below 0.05 ) which indicates that this hypothesis is accepted. Choi and Kim (2013, p. 241) state that the perceived quality of services and products affects how high the value perceived by customers is. Quality service shows that the service meets customer expectations. When the service has customer expectations, the customer feels that the service has high value. For this reason, the level of perceived service quality determines the level of perceived value perceived by customers. The results showed that when the employee service from Myoung Ga Korean Restaurant in Surabaya is fast, good or friendly, and the menu is easy to understand, it will increase Perceived Value, feel overall satisfaction with the speed and kindness of employee service, and easy. he understood the menu of the Myoung Ga Korean Restaurant in Surabaya.

Then in the third hypothesis, Food Quality has a significant effect on Positive Emotions. This hypothesis is supported by the $t$ test where the significance is 0.002 (below 0.05 ) which indicates that this hypothesis is accepted. Previous research has suggested that various food attributes are considered a real cue (Jang, Ha, \& Park, 2012). Customers use cues to determine food quality, which significantly influences satisfaction and behavior. Thus, the high quality of food causes more positive emotions and provides a better perception of value regarding the experience when dining at a restaurant. The results showed that the presence of good food quality (for example: good taste) will increase the customer's Positive Emotions, which will lead to an overall feeling of satisfaction with the quality of the food itself at Myoung Ga Korean Restaurant in Surabaya.

In the fourth hypothesis, Food Quality has a significant effect on Perceived Value. This hypothesis is supported by the $t$ test where the significance is 0.000 (below 0.05 ) which indicates that this hypothesis is accepted. In the restaurant industry, food is also considered as one of the most important factors that lead to satisfaction and loyalty (Clark and Wood, 1999; Namkung and Jang, 2007; Sulek and Hensley, 2004). Previous studies examined the importance of food quality in restaurant marketing assessing food quality using various food attributes, such as presentation, menu variation, healthy choices, taste, freshness, and temperature (Kivela et al., 2000; Raajpoot, 2002; Namkung and Jang, 2007). And the results of this study indicate that the good quality of food, consisting of presentation, menu variations and freshness, will increase Perceived Value, which will trigger a positive overall impression of the quality at Myoung Ga Korean Restaurant in Surabaya.

In the fifth hypothesis, Atmospherics has a significant effect on Positive Emotions. This hypothesis is supported by the $t$ test where the significance is 0.019 (below 0.05) which indicates that this hypothesis is accepted. Atmospherics according to Kotler (1973) is an attempt to design a purchasing environment in order to produce certain emotional effects on consumers in order to increase the probability of buying. Meanwhile, according to Kotler (1973) Atmospherics can be a marketing tool to produce positive behavior in a consumption situation where the product or service is consumed (Ha \& Jang, 2010). So it is also in line with this research which shows that the good components that are part of the restaurant atmosphere such as design, decoration and music will increase the Positive Emotion of customers at Myoung Ga Korean Restaurant in Surabaya.

In the sixth hypothesis, Atmospherics has a significant effect on Perceived Value. This hypothesis is supported by the test where the significance is 0.000 (below 0.05) which indicates that this hypothesis is accepted. The atmosphere is a planned atmosphere in accordance with the target market and which can attract consumers to buy (Kotler, 2005). Levy and Weitz (2007) consumer buying behavior is also influenced by the amosphere. Liberman (2002) states that the interior of a restaurant will determine whether a restaurant can survive or not. Therefore, the results of this study also show that a planned atmosphere both inside and outside the restaurant has the potential to increase Perceived Value, which means it can make Myoung Ga Korean Restaurant in Surabaya last long and have good value.

The seventh hypothesis is that the Authenticity of Food has a significant effect on Positive Emotions. This 
hypothesis is supported by the t test where the significance is 0.013 (below 0.05 ) which indicates that this hypothesis is accepted. The unique environment of an ethnic restaurant can add pleasure value for consumers which is reflected in the authenticity of the food and to taste or experience other cultures as well as a means of communication between food, foreign cultures and local customers (Jang and Ha, 2012: 204; Van den Berghe 1984, in Clemes, 2013: 414; Wood and Munoz 2007, in Jang et al, 2011: 663). This research research is also in line with this statement, which shows that the authenticity of food that refers to Korean culinary is proven to increase Positive Emotions, in this case is the value of customer pleasure at Myoung Ga Korean Restaurant in Surabaya.

In the eighth hypothesis, Authenticity of Food has a significant effect on Perceived Value. This hypothesis is supported by the t test where the significance is 0.025 (below 0.05) which indicates that this hypothesis is accepted. According to Liu and Jang (2009b), authenticity (Authenticity) refers to whether the food and the environment reflect a "authenticity" reality of a certain ethnic culture. Meanwhile, according to Wood and Munoz (2006), some experts conclude that even describing a typical restaurant as two cultures from the country of origin and the experience of eating at a typical restaurant is considered a culinary tour. And the results of this study indicate that the food in Myoung Ga reflects the original Korean culture and indirectly increases Perceived Value, where this has a positive effect on the authenticity of food at Myoung Ga Korean Restaurant in Surabaya.

In the ninth hypothesis, Authenticity of Atmospherics has a significant effect on Positive Emotions. This hypothesis is supported by the t test where the significance is 0.043 (below 0.05) which indicates that this hypothesis is accepted. Ethnic restaurant is a restaurant that combines themes or concepts that lead to an ethnicity of an area with cuisine in order to add to the experience for its consumers (Walker, 2009: 218; Barrows et al, 2012: 73). Authenticity prioritizes food and the characteristics of a certain regional cultural tradition so that it can reflect the true taste of the cultural environment of a particular ethnicity (Ebster and Guist, 2004: 43, in Maria Anggia, 2014: 978; Verbeke and López, 2005 in Jang et al, 2012: 993). This research also reflects the same thing, namely the authenticity of the Myoung Ga restaurant by representing the South Korean atmosphere which has the potential to increase the positive emotions of the Myoung Ga Korean Restaurant customers in Surabaya.

In the tenth hypothesis, Authenticity of Atmospherics has a significant effect on Perceived Value. This hypothesis is supported by the t test where the significance is 0.014 (below 0.05) which indicates that this hypothesis is accepted. The existence of an atmospheric aspect in a restaurant is one of the reasons for the desire for consumers to visit and make purchases. Hughes, 1995; Wang, 1999; Kim et.al, 2009; in Jahromy \& Tajik, 2011: 17 argues that "authenticity is considered one of the factors that influence the experience of tourists visiting a restaurant. Authenticity connotes traditional origin and culture, authentic, real and unique taste. " Beardsworth and Bryman, 1999; Liu and Jang, 2009, in Jang et al, 2011: 667 reveal that "authentic atmosphere is the use of art, ethnicity, decoration, music, outer terrace, names, and various classical markers to create a special arrangement that places demands to be a reflection of some exoticism but able to introduce a culture. " According to Ebster and Guist (2005) in Lu et al (2015: 37). Therefore, the results of this study also show that the use of elements such as art, ethnicity, decoration, music and a typical Korean traditional restaurant environment has a good enough effect on the level of Perceived Value of customers at Myoung Ga Korean Restaurant in Surabaya.

The eleventh hypothesis is that Perceived Value has a significant effect on Behavioral Intentions. This hypothesis is supported by the t test where the significance is 0.000 (below 0.05) which indicates that this hypothesis is accepted. According to Zaithaml (1998), stated that perceived value plays an important role in consumer purchasing decisions, indicating that behavioral intention is a consequence of perceived value (Ha \& Jang, 2010). Ryu, Han, and Kim (2008) examined the relationship between restaurant image, perceived value, 
customer satisfaction, and behavioral intentions in casual restaurants and found that perceived value had a significant role in influencing behavioral intentions. This statement is supported by the results of this study where intense behavioral intentions can trigger sustainable purchases at Myoung Ga Korean Restaurant in Surabaya.

The twelfth hypothesis, namely Perceived Value, has a significant effect on Positive Emotions. This hypothesis is supported by the $t$ test where the significance is 0.000 (below 0.05) which indicates that this hypothesis is accepted. Research conducted by Rachmawati (2009) when value is combined with positive emotion, then any increase or decrease in value can affect impulse buying. Research conducted by Rohman (2009) also obtained the same results where the more positive influence of the consumer's mood, the higher the hedonic consumption value. Research conducted by Amiri et al. (2012) shows that hedonic competition tendency has a positive effect on positive emotion during impulse buying. This research is also in line with this statement, which shows that the fluctuations in the value received by customers can well influence customer impulse buying, which refers to an increase in the positive emotions of customers at Myoung Ga Korean Restaurant in Surabaya.

And the last hypothesis is the thirteenth which states that Positive Emotions has a significant effect on Behavioral Intentions. This hypothesis is supported by the t test where the significance is 0.000 (below 0.05 ) which indicates that this hypothesis is accepted. According to Jang and Namkung (2009) and Liu and Jang (2009a, b), using the development of the Mehrabian-Russell model also found that the emotions generated by dining factors significantly influence consumer behavior in the future, such as positive revisit intentions and worth of mouth. . Empirical research shows a positive relationship between positive emotions and behavioral intention in different service environments. This research is also in line with this statement, which shows that there is positive feedback from customers who in the questionnaire want to come back (revisit intentions) to Myoung Ga Korean Restaurant in Surabaya where this will also have a positive impact on the sustainability and existence of the restaurant.

\section{Conclusion}

Based on the data processing that has been done, the results of thirteen hypotheses are all accepted. There is a significant relationship between Service Quality to Positive Emotion, Service Quality to Value, Food Quality to Positive Emotion, Food Quality to Value, Atmospherics to Positive Emotion, Atmospherics to Value, Authenticity (Food) to Positive Emotion, Authenticity (Food) to Value, Authenticity (Atmospheric) for Positive Emotion, Authenticity (Atmospherics) for Value, Value for Behavioral Intentions, Value for Positive Emotion, and Positive Emotion for Behavioral Intentions.

Managerial Implications

\begin{tabular}{|c|c|}
\hline Current Research & Managerial Implications \\
\hline $\begin{array}{l}\text { Positive emotion is the mood, which determines the } \\
\text { intensity of consumer decision making in shopping } \\
\text { (Tirmizi, 2009). }\end{array}$ & $\begin{array}{l}\text { 1. Maintain and even enhance these positive } \\
\text { emotions by offering a welcome drink } \\
\text { containing spices with fatigue relief benefits } \\
\text { such as ginger or ginseng. } \\
\text { 2. play slow or relaxing Korean acoustic music } \\
\text { 3. direct each waiter to welcome and serve } \\
\text { customers who come cheerfully and full of } \\
\text { empathy. In addition, by providing refreshing } \\
\text { drinks such as soda that can make customers } \\
\text { even more excited } \\
\text { 4. provides a choice of side dishes that vary every } \\
\text { day and for free. Side dishes such as Gamjajeon }\end{array}$ \\
\hline
\end{tabular}




\begin{tabular}{|c|c|}
\hline & $\begin{array}{l}\text { (Korean pancake made from potato), Nakji } \\
\text { bokkeum (sauteed octopus), or Kongnamul } \\
\text { muchim (sprouts and seasoned soybeans) }\end{array}$ \\
\hline $\begin{array}{l}\text { Perceived value is the ultimate goal that consumers } \\
\text { want from their purchasing behavior and is } \\
\text { associated with successful exchange transactions in } \\
\text { consumption situations (Ostrom and Iacobucci, } \\
\text { 1995; Woodruff and Gardial, 1996; Patterson and } \\
\text { Spreng, 1997). }\end{array}$ & $\begin{array}{l}\text { 1. put a detailed price on the receipt, where on the } \\
\text { receipt there is also tax and service charge. } \\
\text { 2. provide a photo spot with a Korean theme that } \\
\text { is tailored to existing events, for example for } \\
\text { the Christmas edition such as in Korea. } \\
\text { 3. always use trusted fresh ingredients and write } \\
\text { down the vitamin content for menus served as } \\
\text { side dishes so that customers know the benefits } \\
\text { of the food eaten }\end{array}$ \\
\hline $\begin{array}{l}\text { Food quality is a quality characteristic of food that is } \\
\text { acceptable to consumers, such as size, shape, color, } \\
\text { consistency, texture, and taste (Potter and Hotchkiss, } \\
2012 \text { ). }\end{array}$ & $\begin{array}{l}\text { 1. Korean Restaurant Myoung Ga in Surabaya to } \\
\text { be able to carry out Quality Control regularly } \\
\text { on every food ingredient to avoid cooking } \\
\text { ingredients that are not fresh } \\
\text { 2. Prioritizing taste and beautiful platting } \\
\text { techniques to produce a special presentation } \\
\text { and composition of food that have a positive } \\
\text { impact on the value received by customers. } \\
\text { 3. Paying attention to the cleanliness and } \\
\text { freshness of cooking ingredients and } \\
\text { processing dishes with good techniques so as to } \\
\text { produce delicious food }\end{array}$ \\
\hline $\begin{array}{l}\text { Authenticity of food is one of the most important } \\
\text { aspects of a restaurant because authenticity refers to } \\
\text { whether the food reflects the "authenticity" of the } \\
\text { ethnic origin culture of the area of origin, and } \\
\text { investigates customer perceptions of the restaurant } \\
\text { (Lego et al, 2002). }\end{array}$ & $\begin{array}{l}\text { 1. learn the ingredients and recipes of traditional } \\
\text { Korean food and then apply them to Myoung } \\
\text { Ga dishes. In addition, at certain times, they } \\
\text { regularly invite chefs from Korea who have } \\
\text { traditional Korean cooking skills to become } \\
\text { quest chefs in Myung Ga. } \\
\text { 2. processing their own Kimchi based on original } \\
\text { Korean recipes, without buying finished } \\
\text { ingredients such as instant Kimchi sauce and } \\
\text { avoiding the taste modification that other } \\
\text { restaurants usually do in order to adapt it to } \\
\text { Indonesian tastes } \\
\text { maintain and even improve this indicator by } \\
\text { educating the cook and his assistants about } \\
\text { traditional Korean plating techniques and } \\
\text { providing cutlery (especially plates and bowls) } \\
\text { which are also traditional Korean }\end{array}$ \\
\hline $\begin{array}{l}\text { Service Quality is how far the difference between } \\
\text { expectations and reality of restaurant customers for } \\
\text { the service received (Parasuraman, Berry and } \\
\text { Zenthaml, 2006). }\end{array}$ & $\begin{array}{l}\text { 1. Improve fast service by educating waiters to } \\
\text { stay concentrated and nimble in serving each } \\
\text { customer. } \\
\text { 2. Provide sufficient knowledge to each waiter in } \\
\text { order to answer questions well. } \\
\text { 3. Provide an informative menu. } \\
\text { 4. Optimizing the employees of Myoung Ga }\end{array}$ \\
\hline
\end{tabular}




\begin{tabular}{|c|c|c|}
\hline & & $\begin{array}{l}\text { Korean Restaurant in Surabaya to be faster, } \\
\text { better or friendlier. }\end{array}$ \\
\hline $\begin{array}{l}\text { Authenticity of atmosphere is a measure of whether } \\
\text { the atmosphere in a restaurant reflects a certain } \\
\text { cultural or ethnic reality (Rahab, 2015). }\end{array}$ & 3. & $\begin{array}{l}\text { applying an interior design that is identical to a } \\
\text { traditional Korean restaurant, such as a floor } \\
\text { seating and dining table, as well as a base that } \\
\text { is dominated by wood panels } \\
\text { Choose songs that are classic and instrumental } \\
\text { and avoid modern songs } \\
\text { maintains a simple and neat design, decorated } \\
\text { with wooden poles like a traditional Korean } \\
\text { restaurant but can also add to event themes such } \\
\text { as Christmas, New Year but with a Korean feel }\end{array}$ \\
\hline $\begin{array}{l}\text { Atmospherics is designing an environment through } \\
\text { visual communication, lighting, color, music, and } \\
\text { smell in a restaurant to stimulate the perceptions and } \\
\text { emotions of customers and ultimately to influence } \\
\text { their shopping behavior on restaurant menus (Levy } \\
\text { and Weitz, 2001). }\end{array}$ & 7. & $\begin{array}{l}\text { adapting existing decorations in an authentic } \\
\text { restaurant in Korea to the restaurant with a few } \\
\text { modern modifications, for example adding an } \\
\text { 'instagramable' photo spot so that the } \\
\text { decoration attracts the attention of customers } \\
\text { who come } \\
\text { Apply interior paint with soft colors that } \\
\text { represent authentic restaurants in Korea, such } \\
\text { as beige, ivory white and dark brown } \\
\text { play soft Korean traditional music at a volume } \\
\text { that doesn't dominate the room too much } \\
\text { 4.Decorating the exterior of the restaurant with } \\
\text { references to authentic restaurants in Korea, as } \\
\text { well as with classic Korean ornaments such as } \\
\text { welcome greetings with Korean characters } \\
\text { using natural aromatherapy with the aroma of } \\
\text { chamomile or green tea } \\
\text { displaying works of art typical of South Korea } \\
\text { that are compatible with restaurants such as } \\
\text { paintings or other wall displays, as well as } \\
\text { lining some parts of the interior with wood } \\
\text { panels to add a traditional impression } \\
\text { using an LED lamp with a color temperature of } \\
2700 \text { - 5000 kelvin where in that temperature } \\
\text { range it produces warm white to soft white } \\
\text { glow } \\
\text { Arranging the dining table and chairs neatly } \\
\text { and apart from one table to another customer } \\
\text { table, as well as the selection of a wide dining } \\
\text { table considering that the Korean food menu is } \\
\text { guite diverse }\end{array}$ \\
\hline
\end{tabular}

\section{Recommendation}

- Seeing the limitations regarding the research object that only takes respondents, namely customers from Myoung Ga Korean Restaurant in Surabaya, it is hoped that the next research using the same or 
modified model can be applied to different objects to get more general results on the factors that affect behavioral intentions.

- Further research is expected to complement the existing variables in this research so that it can further enhance understanding of the factors that affect behavioral intentions, such as the addition of price variables or other variables.

- Further research can be developed by linking the factors that influence behavioral intentions based on income level, age, and gender. Future research can also expand the scope of respondents who will be researched, or carry out their research in a different area from the current research, so that further research is being carried out to provide a broader picture of behavioral intentions.

\section{References}

Jang, S. C., Ha, J., \& Park, K. (2012). Effects of Ethnic Authenticity: Investigating Korean Restaurant Customers in the U.S. International Journal of Hospitality Management, 31, 990- 1003.

Jang, S. C., Liu, Y., \& Namkung, Y. (2011). Effects of Authentic Atmospherics in Ethnic Restaurants: Investigating Chinese Restaurants. International Journal of Contemporary Hospitality Management. 23(5), 662-680

Lu, A. C. C., Gursoy, D., \& Lu, C. Y. (2015). Authenticity perceptions, brand equity and brand choice intention: The case of ethnic restaurants. International Journal of Hospitality Management, 50, 36 - 45

Berman, B., \& Evans, J. R. (2010). Retail Management : A Strategic Approach (11th Ed.).

Berry, L. L., Parasuraman, A. (1991). Marketing Services: Competing Through Quality.

Sik C. H. (2006). Food and Nationalism: Kimchi and Korean National Identity. The Korean Journal of International Studies 4-1, 207-29

Baker, D. A., \& Crompton, J. L. (2000). Quality, satisfaction and behavioral intentions. Annals of Tourism Research, 27(3), 785-804.

Thabroni, G. (2020). Pengertian Budaya., Unsur, Wujud \& Fungsi Menurut Para Ahli. (https://serupa.id/budaya-pengertian-unsur-wujud/). Diakses pada 07 Juli 2020.

Sukoyo, Y. (2019). Indonesia Berpeluang Kembangkan Budaya Populer. (https://www.beritasatu.com/nasional/581713-indonesia-berpeluang-kembangkan-budaya-populer). Diakses pada 09 Juli 2020.

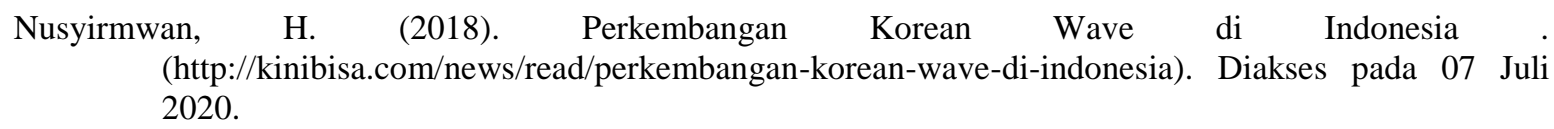

Canny, I. U., (2014). Measuring The Mediating Role of Dining Experience Attributes on Customer Satisfaction 
and Its Impact on Behavioral Intentions Of Casual Dining Restaurant in Jakarta. International Journal of Innovation, Management and Technology, 5(1):25-29.

Jang, S. C., \& Ha, J. (2012). The Effect of Dining Atmospherics on Behavioral Intentions Through Quality Perceptions. Journal of Services Marketing, 26/3, 204-215.

Kotler, P., \& Keller, K. L. (2008). Marketing Management: An Asian Perspective - 5th Edition.

Qin, H., \& Prybutok, V. R. (2009). Service Quality, Customer Satisfaction, and Behavioral Intention in FastFood Restaurants.International Journal of Quality and Services Sciences, Vol. 1, No. 1, pp. 78-95.

Ryu, K., Lee, H. R., \& Kim, W., G. (2011). The Influence of The Quality of The Physical Environment, Food, and Services on Restaurant Image, Customer Perceived Value, Customer Satisfaction, and Behavioral Intentions. Intenational Journal of Contemporary Hospitality Management, Vol. 24, No. 2, pp. 200-223.

Schmitt, B. H. (1999). Experiential Marketing: How to Get Customers to Sense, Feel, Think, Act, Relate to Your Company and Brands.

Kivela, J., Inbakaran, R., Reece, J., (2000). Consumer research in the restaurant environment. Part 3: analysis, findings and conclusions. International Journal of Contemporary Hospitality Management 12 (1), $13-30$.

Sulek, J. M., \& Hensley, R. L. (2004). The relative importance of food, atmosphere, and fairness of wait.Cornell Hotel and Restaurant Administration Quarterly, vol. 45(3), pp. 235-247.

Ha, J., \& Jang, S.S., (2010). Effects of service quality and food quality: the moderating role of atmospherics in an ethnic restaurant segment. International Journal of Hospitality Management 29 (3), pp. 520-529.

Ponnam, A. P., \& Balaji, M. S. (2014). Matching visitation-motives and restaurant attributes in casual dining restaurants. International Journal of Hospitality Management, vol. 37, pp. 47- 57

Man, J. J., Sydnor, S., Lee, S. K., \& Almanza, B. (2015). A conflict of choice: How consumers choose where to go for dinner. International Journal of Hospitality Management, vol. 45, pp. 88-98

Namkung, Y., \& Jang, S. (2008). Does food quality really matter in restaurants? Its impact on customer satisfaction and behavioral intentions. Journal of Hospitality and Tourism Research, vol. 31(3), pp. 387-409.

Liu, Y. H., \& Jang, S. (2009), The effects of dining atmospherics: an extended Mehrabian-Russell model, International Journal of Hospitality Management, Vol. 28 No. 4, pp. 494-503.

Ryu, Kisang, Lee, H. R., \& Kim, W. G. (2012). The influence of the quality of the physical environment, food, and service on restaurant image, customer perceived value, customer satisfaction, and behavioral intentions. International Journal of Contemporary Hospitality Management, vol. 24, no. 2, pp. 200223.

Chen, Chen, H. B., Yeh, S. S, \& Huan, T. C. (2014). Nostalgic emotion, experiential value, brand image, and 
consumption intentions of customers of nostalgic-themed restaurant. Journal of Business Research, vol. 67 , pp. $354-360$.

Nugroho, A. (2013). Pengaruh kualitas lingkungan fisik, kualitas makanan, kualitas pelayanan pada restaurant image, perceived value, kepuasan konsumen, dan behavioral intention. Skripsi Fakultas Ekonomi Universitas Sebelas Maret.

Hutama, C. L, \& Subagio, H. (2014). Analisa pengaruh dining experience terhadap behavioral intention dengan customer satisfaction sebagai variabel intervening (studi kasus : domicile kitchen and lounge). Jurnal Manajemen Pemasaran Petra, vol. 2, no. 1 